\title{
Feedback on research results to healthcare professionals in the context of HIV
}

\author{
Devolutiva de resultados de pesquisa a profissionais de saúde no contexto HIV \\ Devolutiva de resultados de investigación a profesionales de la salud en el contexto VIH
}

\section{lací Proença Palmeira' \\ ORCID: 0000-0001-9659-3565 \\ Ivaneide Leal Ataíde Rodrigues' \\ ORCID: 0000-0001-9968-9546 \\ Elizabeth Teixeira" \\ ORCID: 0000-0002-5401-8105 \\ Bruna Alessandra Costa e Silva Panarra"' Ana Isabella Sousa Almeida"v Daiane Freitas Carneirov ORCID: 0000-0002-5653-033X}

Sâmela Stefane Corrêa Galvãovı

' Universidade do Estado do Pará. Belém, Pará, Brazil.

"Universidade do Estado do Rio de Janeiro. Rio de Janeiro, Rio de Janeiro, Brazil.

"'Universidade da Amazônia. Belém, Pará, Brazil.

" Escola Nacional de Saúde Pública Sergio Arouca. Rio de Janeiro, Rio de Janeiro, Brazil.

$\checkmark$ Instituto Evandro Chagas. Belém, Pará, Brazil.

v'Universidade Federal do Pará. Belém, Pará, Brazil

How to cite this article:

Palmeira IP, Rodrigues ILA, Teixeira E, Panarra BACS, Almeida AIS, Carneiro DF, et al. Feedback on research results to healthcare professionals in the context of HIV. Rev Bras Enferm. 2019;72(5):1416-20. doi: http://dx.doi.org/10.1590/0034-7167-2017-0875

Corresponding Author: lací Proença Palmeira

E-mail: iaci_palmeira@yahoo.com.br

Submission: 11-20-2017

Approval: 03-05-2018

\section{ABSTRACT}

Objective: Reporting the feedback on the results of a multicenter research for healthcare professionals that attend people living with HIV and AIDS in a Specialized Healthcare Center at Belém, state of Pará, Brazil. Method: Case report of the presentation and interpretation of research results, in 2015, totaling 25 participating professionals. The visual resource used was a data projector. Results: Participants reported the importance of the initiative, since, even though it is their right, feedback on research results is uncommon. Among the discussed issues, emerged the need for a culturally appropriate device for adequately strengthening educational practices carried out by healthcare professionals. Conclusion: Feedback on the research results enabled exchange of knowledge about the findings and production of new knowledge. In addition to achieving the social and ethical commitment of research, by promoting dissemination of results, enabling reflections on the reality in which they work.

Descriptors: HIV; AIDS; Healthcare Personnel; Healthcare Education; Healthcare Technology.

\section{RESUMO}

Objetivo: Relatar a devolutiva dos resultados de uma pesquisa multicêntrica para profissionais de saúde que atendem pessoas que vivem com HIV e aids em uma Unidade de Referência Especializada de Belém, Pará, Brasil. Método: Relato de experiência da apresentação e interpretação dos resultados da pesquisa, no ano de 2015, totalizando 25 profissionais participantes. Utilizou-se como recurso visual o Datashow. Resultados: Os participantes relataram a importância da iniciativa, pois, mesmo sendo direito deles, não são comuns as ações de devolução dos resultados de pesquisas. Dentre as questões discutidas, emergiu a necessidade de um dispositivo culturalmente adequado para o fortalecimento das práticas educativas realizadas pelos profissionais. Conclusão: A devolutiva dos resultados da pesquisa possibilitou troca de saberes sobre os achados e produção de novos conhecimentos. Também possibilitou alcançar o compromisso social e ético da pesquisa, ao promover difusão dos resultados, propiciando reflexões sobre a realidade em que atuam. Descritores: HIV; Aids; Pessoal de Saúde; Educação em Saúde; Tecnologia em Saúde.

\section{RESUMEN}

Objetivo: Relatar la devolutiva de los resultados de un estudio multicéntrico para profesionales de salud que atienden a personas que viven con VIH y sida en una Unidad de Referencia Especializada de Belém, Pará, Brasil. Método: Relato de experiencia de la presentación e interpretación de los resultados de la investigación, en el año 2015, totalizando 25 profesionales participantes. Se utilizó como recurso visual el Data Show. Resultados: Los participantes relataron la importancia de la iniciativa, pues, aun siendo derecho de ellos, no son comunes las acciones de devolución de los resultados de investigaciones. Entre las cuestiones discutidas, surgió la necesidad de un dispositivo culturalmente adecuado para el fortalecimiento de las prácticas educativas realizadas por los profesionales. Conclusión: La devolución de los resultados de la investigación posibilitó el intercambio de saberes sobre los hallazgos y la producción de nuevos conocimientos. También permitió alcanzar el compromiso social y ético de la investigación, al promover la difusión de los resultados, propiciando reflexiones sobre la realidad en que actúan.

Descriptores: VIH; Sida; Personal de Salud; Educación en Salud; Tecnología Biomédica. 


\section{INTRODUCTION}

AIDS (Acquired Immune Deficiency Syndrome) emerged in Brazil in mid-1980s as a threatening and terrifying epidemic. A time marked by strong stigma associated with the disease, characterized by family abandonment and intense prejudice on the part of healthcare professionals and general population. At the beginning of the epidemic, since the etiologic agent and the means of transmission were unknown, stigma and discrimination were manifested in several ways such as in the following expressions: "gay cancer," "the wrath of God," or "gay plague"(1).

Although there have been many advances in the sense of controlling the epidemic and expanding its treatment, the disease is far from disappearing. According to a report from the Global Aids Update: Ending Aids - Progress towards the 90-90-90 targets ${ }^{(2)}$, released by the United Nations program "The Joint United Nations Programme on HIV/AIDS (Unaids)," the number of new infections by the human immunodeficiency virus (HIV) has been slowly reducing worldwide.

Between 2010 and 2015, the number of new infections in adults remained static, but at levels still high, accounting for 1.9 million of new infections per year (1.7 million to 2.2 million). However, in 2017, according to estimates, new infections in adults have fallen $8 \%$ between 2010 and 2015, and 11\% between 2010 and 2016. Brazil is the most populous country of Latin America and also the one with most new cases of HIV - data show that the country accounts for $49 \%$ of new infections, which is equal to 48 thousand new cases per year ${ }^{(2)}$.

In our study we address a feedback on results of a multicenter research,"As transformações do cuidado de saúde e enfermagem em tempos de aids: representações sociais e memórias de enfermeiros e profissionais de saúde no Brasil" [Transformations in health care and nursing within the AIDS context: social representations and memories of Brazilian nurses and healthcare professionals], carried out from 2009 to 2013 in 12 municipalities of the country, in different states. The experience we report addresses the feedback on the findings gathered in the state of Pará.

A quality survey comprises both the theoretical production and the feedback on its results directed to the participants of the study and the overall scientific community. Presenting the research results is extremely important, since it allows participants to approach the study object in order to share its results, presenting reflections, and showing the relevance of its contribution, in addition to enabling the verification of collected information ${ }^{(3)}$.

Research involving human beings needs to meet scientific and ethical principles. One of them is to ensure participants the benefits obtained from the project - namely the social feedback ${ }^{(4)}$. This case report is justified within this context of the researchers' commitment.

The Code of Ethics of Nursing Professionals, on Chapter III, which addresses education, research and scientific-technical production matters, regarding the responsibilities and duties of nursing professionals, highlights: "to make available research results to the scientific community and overall society"(5). The responsibility on the agenda in such code can emerge through the feedback on results and their diffusion in scientific journals as well as in lectures.

In this report, the feedback on the results was effective through lectures and dialogue between members of the multicenter research and healthcare professionals of a Specialized Healthcare
Center, professionals who are directly involved in attending people living with HIV and AIDS (PLWHA).

The report is relevant because there are gaps in the scientific production in Brazil concerning articles on experiences of feedback on results, which report how researchers enabled such feedback, after the completion of the research. Scarcity of this type of study was evidenced with the survey on the state of the art, using the following databases: LILACS, MEDLINE, and BDENF considering the period from 2013 to 2016. In this search we found two articles ${ }^{(6-7)}$ addressing the issue. According to the result, overall, such issue is poorly addressed in all fields of knowledge.

In the identified studies, authors mention the contributions of feedbacks on research results, and some of these contributions are dialogue, sharing and exchange of knowledge, expansion of the produced knowledge, and the ethical conduct of researchers, among others ${ }^{(6-7)}$.

It is noteworthy that the multicenter research data, which were presented and discussed with healthcare professionals that daily attend PLWHA, can help minimizing the stigma and the prejudice that are still manifested in this context of health care.

\section{OBJECTIVE}

Reporting the feedback on the results of a multicenter research for healthcare professionals that attend people living with HIV and AIDS in a Specialized Healthcare Center at Belém, state of Pará, Brazil.

\section{METHOD}

\section{Ethical aspects}

After observing the norms of Resolution 466/12 of the National Council of Health the project was approved. All participants signed the Informed Consent Form at the feedback site.

\section{Type of study}

Case study of the feedback on results of a multicenter study for healthcare professionals in the city of Belém, Pará. The feedback was mediated by researchers of the research groups Grupo de Pesquisa Práticas Educativas em Saúde e Cuidado na Amazônia (Educational Practices on Health Care in the Amazon - Pesca) and Enfermagem e Representações Sociais na Atenção à Saúde (Nursing and Social Representations in Health Care - Eras) linked to Pará State University (Uepa).

The multicenter research entitled As transformaçōes do cuidado de saúde e enfermagem em tempos de aids: representações sociais e memórias de enfermeiros e profissionais de saúde no Brasil [Transformations in health care and nursing within the AIDS context: social representations and memories of Brazilian nurses and healthcare professionals] was carried out from 2009 to 2013 in 12 municipalities - referred to as sites - of different states, and Belém was one of them.

In its turn, the feedback was the first stage of the second study conducted in Belém, involving both research groups and entitled Educação em saúde em tempos de HIV em contexto amazônico [Healthcare education about HIV within the Amazon context] 
approved by the CNPq call for submissions and carried out from 2013 to 2016. The authors-researchers of both groups participated in the first study and enabled the feedback in the second one.

\section{Methodological procedures}

Healthcare professionals were firstly approached by the researchers' visit to the site chosen for the feedback, aiming at identifying the possibility of holding meetings with the team of professionals. Henceforth, we testified that the proposal was accepted by the board of the Healthcare Center and, together with its manager, we discussed the best strategy to encourage professionals in participating in the meetings. We defined that the very management of the Healthcare Center would promote and invite professionals to participate in such meetings.

In order to formalize the meetings, an invitation was sent to the Healthcare Center requesting the indication of the best location, day, and time of the meetings, according with the availability of healthcare professionals. After defining the dates, posters were fixed in murals of the Healthcare Center with information about the meetings.

\section{Study scenario}

The location chosen was the meeting room of the Reference Healthcare Center Specialized in Infectious and Parasitic Diseases (Unidade de Referência Especializada em Doenças Infecciosas Parasitárias Especiais - Uredipe), located in Belém, Pará, Brazil. The room had proper structure, located on the second floor of the building $-a$ welcoming environment with privacy and adequate temperature.

The discursive production of the first study, submitted to the analysis of lexical content, generated five classes. For the second study, focused on healthcare education within the context of HIV/ AIDS, class 1 was chosen, which featured the category "healthcare education", since it emphasized the dynamics of the health care provided and educational process. This class, addressed with more emphasis during the feedback, encompasses lexicons analyzing the "healthcare education" category, represents 33\% of the corpus analyzed and contains 888 Special Healthcare Centers. It is noteworthy that this class was the object of a post-doctoral study of one of the authors ${ }^{(8)}$, which enabled the deepening of results and discussion presented in the report of the multicenter study.

\section{Information sources}

A total of 25 healthcare professionals participated in the study, namely: 5 nurses, 4 social workers, 2 physicians, 3 psychologists, 2 pharmacists, 1 nutritionist, 6 nursing technicians, and 2 radiology technicians.

\section{Study steps}

There were two meetings on February 2016. The first was held in the morning, in the period from 9:00 a.m. to 12:00 a.m., and the second, in the afternoon, from 2:30 p.m. to 4:00 p.m. The results of the multicenter study were presented and there were collective discussions.
In the meetings, the printed report was exposed and discussed, and the general results of the study were projected by using a data projector. Then, participants identified the weaknesses in their practices and suggested possible actions for enhancing the attendances in the Healthcare Center, mainly regarding the development and promotion of self-care actions between PLWHA.

In each meeting there were: a) presentation of the team of facilitators and healthcare professionals participating in the study; b) presentation of the main results of the multicenter research and of the study on the "healthcare education" category; c) presentation of the project Educação em saúde em tempos de HIV/aids em contexto amazônico [Healthcare education about HIV within the Amazon context]; d) report of healthcare professionals concerning the findings of the survey and the new project. As a means of evaluation, participants commented about the experience to participate in lectures and made suggestions regarding healthcare education in the Center.

\section{RESULTS}

\section{Lessons learned from the exchange of knowledge and dialogue with the team}

After welcoming the team and identifying all participants, the facilitators started the presentation, which was organized into seven parts: presentation of 1) places where the multicenter research was developed; 2) participating professionals throughout the country; 3 ) general goal and strategies for data collection and analysis; 4) results of the mentions of the term "HIV and AIDS in Brazil," and of "HIV and attending PLWHA in Pará," with highlight to the "healthcare education" category, which is paramount when attending PLWHA; 5) meaning of healthcare education in the Pará site; 6$)$ the project Educação em saúde em tempos de HIV/aids em contexto amazônico [Healthcare education about HIV within the Amazon context]; 7) next steps and acknowledgments.

In relation to the "healthcare education" category, the team emphasized limiting factors singled out in the multicenter study such as the low valuation of educational actions by participating professionals and lack of culturally appropriate materials. During the presentation, participants agreed that such factors make professionals to not carried out educational activities with PLWHA often.

Another aspect discussed with participating professionals was the combination of pedagogical perspectives found in the discursive material of class 1 of the multicenter study. These perspectives, which guide educational practices, sometimes tend to vertical and traditional pedagogical approaches, sometimes to more horizontal and dialogical ones. Feedback participants stated that the different approaches are really "merged" within their practices, and that both can be powerful and encourage changes in habits of the health care provided to PLWHA.

After finishing the presentation, participating professionals expressed their thoughts about the very feedback, other results, and the new study. Practically all professionals expressed their opinions. These mentioned the importance of the research feedback activity - for them, an unprecedented action that allowed sharing results, since research processes comprise a partnership between interested parties, but not always the researchers return 
to Healthcare Centers where they developed the research with this intention.

In reports there were expressions such as: I've never had a meeting with researchers to be aware of the results of the research; for the first time I get the results of a survey; there have been many researchers in this Center, but none came back.

Regarding results, they highlighted that attending PLWHA is still a challenge, and having healthcare education is even more, because, as some expressed: they come here, but don't want to stay any minute longer after their appointment; they don't come to the Center always, because they send their wives, mothers, brothers, and others to take the medication for them; there's little material of the Brazilian Ministry of Health directed to them, and they are very generic.

Regarding the new project on healthcare education, it was highlighted, in the reports of participating professionals, the need for a culturally appropriate device, aiming at strengthening healthcare education practices carried out in Centers that attend these people, specifically in Pará, which is a state with peculiarities different from other regions of the country and which has great influence of the Indigenous culture on eating habits, cuisine, and healthcare practices. As for the invitation to participate in the next stage of the new project, almost all professionals were favorable.

After the feedback on the results, the new project of participatory approach started, in which an educational technology created by participating professionals was developed in partnership with facilitators.

Feedback on results is a difficult and necessary task, in which researchers disclose the results of the survey with the responsibility of preserving the expressions of individuals, avoiding misunderstandings of the findings ${ }^{(3)}$.

The feedback activity enabled the awareness of participating professionals and the sharing of evidences found in the multicenter study. It also allowed the group itself to recognize the need for an educational technology. Authors were able to undergo an innovative experience, both for themselves and for such professionals, since returning to the Center enabled the exchange of knowledge and the approach between the research team and healthcare professionals. Experiences such as these create opportunities, partnerships, and agreements between researchers and professionals, which are important for developing partnerships for future studies ${ }^{(7)}$.

Studies on feedbacks ${ }^{(6-7)}$ highlight that such are essential to the community, since such moments contribute to dialogue by sharing of knowledge, information, and resolution of doubts. Thus, it is paramount that researchers disclose the results of their studies, in such a way the acquired knowledge is shared, favoring the development of actions towards identified issues and motivating the development of further research ${ }^{(8)}$.

Member States of the Pan-American Health Organization (PAHO) adopted in 2009 the Policy on Research for Health. "The policy adopts a broad approach towards 'healthcare' research which includes intersectoral work and is consistent with the focus on healthcare determinants within all policies. The emphasis of the policy is to strengthen healthcare systems through the development of solid and sustainable systems of healthcare research, in which survey data are the cornerstone of all activities directed to achieving the highest level of health care and equity"(9). The sixth objective of the policy is to promote the dissemination and use of research results.

The scientific, social, and cultural role of research institutions and universities will be fully legitimized when actions for dissemination of knowledge are generated aiming at integrating research and education activities. At the same time, disseminating scientific knowledge is paramount to the criticism and conscious involvement of society in issues concerning science and technology, assuming that these actions can transform people's lives and promote special talents ${ }^{(10)}$.

Healthcare education is a challenge to the extent professionals of this field play a dual role as educators: one with users of the Healthcare Centers and another with the group of healthcare professionals; in both, they develop educational activities as mediators and facilitators of learning ${ }^{(9)}$.

The culture-sensitive educational technologies are created within and considering the reality in which they will be used and may also be constructed with the subjects of the context in which they will be used. Participatory approaches aim at a process in which the creation of knowledge comprises the participation of all those involved - i.e., in our study, among researchers, healthcare professionals, and users -, thus strengthening the effectiveness of the principle of social participation ${ }^{(8)}$.

\section{Study limitations}

It is worthy mentioning the study limitations such as the little production on the subject "feedback on research results," leading to the limitation of discussions and dialogue with other realities. Nevertheless, we understood that there were "learned lessons" and that future research may benefit from similar strategies that, certainly, will bring benefits to the public participating in surveys and to researchers.

\section{Contributions to the field of nursing}

Despite being a right of the participants, to observe actions of feedback on healthcare research with human beings is uncommon. Thus, the need for reflection on what the nursing field is producing and feedback on their research to participants enable the approach between university and healthcare centers and between researchers and research participants, thus working as bases for new studies on the subject.

\section{FINAL CONSIDERATIONS}

Feedback on the research results enabled the dialogue on the findings and indicated the need for creating an educational technology. In addition, it demonstrated that feedback activities are paramount to improving the professional work and must be carried out by researchers in the Healthcare Centers of their research.

With the meetings, participating professionals and the team created a technology to mediate healthcare education practices in the Center. We perceived with the experience that healthcare education is essential to attend PLWHA, which needs to be systematically planned, but also that professionals not always have access to culturally appropriate educational technologies to be used. 
Our study intended to achieve the social and ethical commitment of research, by promoting the dissemination and use of research findings, according with the sixth objective of the Policy on Research for Health. Thus, it enabled professionals participating in the research critical and active appropriation of the reality they are part of, with the opportunity to think about their practice and to promote possible changes required for meeting the healthcare needs of PLWHA and their own.

\section{REFERENCES}

1. Carvalho MS, Paes GO. A influência da estigmatização social em pessoas vivendo com HIV/AIDS. Cad Saúde Colet [Internet]. 2011 [cited 2017 Jul 17];2(19):157-63. Available from: http://www.iesc.ufrj.br/cadernos/images/csc/2011_2/artigos/csc_v19n2_157-163.pdf

2. Joint United Nations Programme on HIV/AIDS. Global AIDS update: Ending AIDS: progress towards the 90-90-90 targets[Internet]. Geneva: Unaids; 2017 [cited 2017 Jul 17]. Available from: https://unaids.org.br/relatorios-e-publicacoes

3. Kramer S. Autoria e autorização: questões éticas na pesquisa com crianças. Cad Pesq [Internet]. 2002 [cited 2017 Jun 22];116(1);41-59. Available from: http://www.scielo.br/pdf/cp/n116/14398.pdf

4. Ministério da Saúde (BR). Conselho Nacional de Saúde. Resolução n 466/12, de 12 de dezembro de 2012. Brasília (DF); 2012.

5. Conselho Federal de Enfermagem. Resolução Cofen no 311/2007. Aprova a reformulação do Código de Ética dos profissionais de enfermagem [Internet]. Rio de Janeiro: Cofen; 2007 [cited 2017 Apr 15]. Available from: http://www.cofen.gov.br/wp-content/ uploads/2012/03/resolucao_311_anexo.pdf

6. Pessanha J, Silva CO, Rotenberg L. Uma experiência de restituição de resultados em saúde do trabalhador. Estud Contemp Subj[Internet]. 2013 [cited 2017 Aug 17];3(1):32-44. Available from: http://www.periodicoshumanas.uff.br/ecos/article/view/1124/817

7. Anjos KF, Boery RNSO, Santos VC, Boery EN. Devolutiva dos resultados de pesquisa desenvolvida com cuidadores familiares de idosos dependentes. Extensio UFSC[Internet]. 2016 [cited 2017 Sep 15];13(23):99-111. Available from: https://periodicos.ufsc.br/index.php/ extensio/article/view/1807-0221.2016v13n23p99/32680

8. Teixeira E, Oliveira DC. Representações sociais de educação em saúde em tempos de AIDS. Rev Bras Enferm[Internet]. 2014 [cited 2017 Jan 15];67(5):810-7. Available from: http://www.scielo.br/pdf/reben/v67n5/0034-7167-reben-67-05-0810.pdf

9. Centro Latino-Americano e do Caribe de Informação em Ciências Sociais. Bireme e a Política de Pesquisa em Saúde da Opas/OMS[Internet]. São Paulo; Boletim Bireme n³. 2016. Available from: http://boletin.bireme.org/pt/2016/12/18/ bireme-e-a-politica-de-pesquisa-em-saude-da-opasoms/

10. Ferretti F, Gris A, Mattiello A, Teo CRPA, Sa C. Impacto de programa de educação em saúde no conhecimento de idosos sobre doenças cardiovasculares. Rev Salud Pública[Internet]. 2014 [cited 2017 Apr 18];16(6):720-32. Available from: http://www.scielosp.org/pdf/rsap/ v16n6/v16n6a01.pdf 